\title{
SOME ASPECTS OF NUTRITION AND MODERATE BODY WEIGHT REDUCTION IN LITHUANIAN OLYMPIC SPORT CENTRE FEMALE BASKETBALL PLAYERS
}

\author{
Marius Baranauskas ${ }^{1,3}$, Linas Tubelis $^{2,3}$, Rimantas Stukas ${ }^{1}$, Edmundas Švedas $^{4}$, \\ Laimutè Samsoniené ${ }^{5}$, Diana Karanauskiene் $\dot{e}^{6}$ \\ Vilnius University Faculty of Medicine Public Health Institute, Vilnius, Lithuania \\ Vilnius Pedagogical University, Vilnius, Lithuania ${ }^{2}$ \\ Lithuanian Olympic Sport Center, Vilnius, Lithuania ${ }^{3}$ \\ Vilnius Sports Medicine Center, Vilnius, Lithuania ${ }^{4}$ \\ Vilnius University Sports and Health Center, Vilnius, Lithuania ${ }^{5}$ \\ Lithuanian Academy of Physical Education, Kaunas, Lithuania ${ }^{6}$
}

\begin{abstract}
Research background and hypothesis. Many athletes know the benefits of low carbohydrate diets these days, but recently healthcare specialists have paid much attention to high carbohydrate diets and safer methods of losing weight.

Research aim was to investigate Lithuanian Olympic Sport Centre female basketball players' $(\mathrm{n}=10)$ actual and special nutrition and their physical condition.

Research methods. Athletes' food records were analyzed and assessed. We determined plasma triacylglycerol, total cholesterol, LDL cholesterol, HDL cholesterol, glucose. Physical Working Capacity $\left(\mathrm{PWC}_{170}\right)$ test was conducted to determine aerobic fitness before and after moderate weight reduction.

Research results showed that the basketball players received too little carbohydrates, linoleic acid, amino acid methionine and too much fat. Vitamins D, PP, $\mathrm{B}_{1}$ and folic acid intakes were insufficient. During moderate bodyweight reduction basketball players significantly decreased in their BW $(-2.2 \pm 0.3 \mathrm{~kg}, \mathrm{p}<0.05), \mathrm{BF}$ $(-1.6 \pm 0.3 \mathrm{~kg}, \mathrm{p}<0.05)$ and minerals $(-0.1 \pm 0.4 \mathrm{~kg}, \mathrm{p}<0.05)$, but they non-significantly decreased in BP $(\mathrm{p}>0.05)$. Furthermore, lipid panels markers (triacylglycerol, total cholesterol, LDL cholesterol, HDL cholesterol) experienced non-significant improvements while glucose levels $(\mathrm{p}<0.05)$ and $\mathrm{PWC}_{170}(\mathrm{p}<0.05)$ resulted in significant decrease following a 12-day hipocaloric diet.

Discussion and conclusions. The results indicate that hipoenergetic moderate weight loss at $<30 \mathrm{kcal} \cdot \mathrm{kg}^{-1}$. day $^{-1},<5 \mathrm{~g} \cdot \mathrm{kg}^{-1} \cdot$ day ${ }^{-1}$ carbohydrate is not recommended for athletes as it can affect aerobic fitness.
\end{abstract}

Keywords: nutrition, female basketball, bodyweight reduction.

\section{INTRODUCTION}

I

$n$ the aspect of duration, body mass reduction can be short-term, lasting for 24-72 hours, moderate, lasting for 72 hours - two weeks, and gradual, lasting from several weeks to several months (Wilmore, 2000). However, it should be noted that most athletes and coaches prefer shortterm body mass reduction and not the one which lasts longer. In both cases the aim is the same to reduce the body mass and to preserve the lean body mass and physical working capacity as much as possible. This concerns female basketball players from the Lithuanian Olympic Sport Center as well because it is very important to them to reduce their fat body mass for better physical, technical and tactical fitness, as those parameters become slower at the age of 15-17 years, and sometimes they even become worse (Balčiūnas et al., 2009). 
Statistical data processing was performed using SPSS v. 15 program package. We applied the following methods of mathematical statistics: calculation of arithmetic means, dispersion of data according to standard deviation (SD), statistical correlations using Pearson's correlation coefficient (r) and coefficient of determination $\left(\mathrm{R}^{2}\right)$, and differences using Student's paired samples t-test. Statistical significance of mean differences was evaluated with a confidence interval of 95 percent, when the significance level was set at $\mathrm{p} \leq 0.05$.

\section{RESEARCH RESULTS}

The study on female basketball players' nutrition (Table 1) revealed that energy received from food, i. e. $40.0 \pm 8.4 \mathrm{kcal} / \mathrm{kg}$ of body mass was sufficient, however, the main nutrients providing energy - carbohydrates and fats - were not balanced in their food rations. If the amount of carbohydrates received from food in 24 hours was $5.0 \pm 0.4 \mathrm{~g} / \mathrm{kg}$ of body mass, which makes only $50.3 \pm 1.9 \%$ from the overall energy value, it was too low and it did not reach the recommended amount $-7-8 \mathrm{~g} / \mathrm{kg}$ of the body mass, the amount of fats was $1.6 \pm 0.2 \mathrm{~g} / \mathrm{kg}$ of the body mass on average, and it exceeded the recommended amount making up $34.7 \pm 1.5 \%$ and thus made a rather high proportion of the energy value from fats.

We established that the qualitative composition of the athletes' food rations did not match the recommendations because female basketball players consumed too much saturated fatty acids and too little polyunsaturated linolenic fatty acids with their food. The $14.7 \%$ energy value of saturated fatty acids exceeded the recommended amount of $10 \%$, and the inadequate amount of linolenic fatty acid which is not synthesized in the human body can be proved by the inadequate ratio of linoleic and linolenic acids $1: 1.8$, while the recommended ratio is $1: 5$. Besides the athletes consumed a greater amount of cholesterol with food $-0.9 \pm 0.2 \mathrm{mg}$, while the recommended norm is $0.5 \mathrm{mg}$.

The amount of proteins in the nutrition of female basketball players was efficient $-1.5 \pm 0.2 \mathrm{~g} / \mathrm{kg}$ of the body mass, and the percent of the energy value of proteins $-15 \pm 0.5 \%$ - corresponds to the recommended norms: from 12 to $15 \%$. On the other hand, athletes' diets lacked amino acid methionine (Table 3 ). The lack is confirmed by the inadequate ratio of three amino acids - tryptophan, methionine and lizine, which is $1: 1.5: 4.6$, and the recommended ratio is $1: 3: 4$.

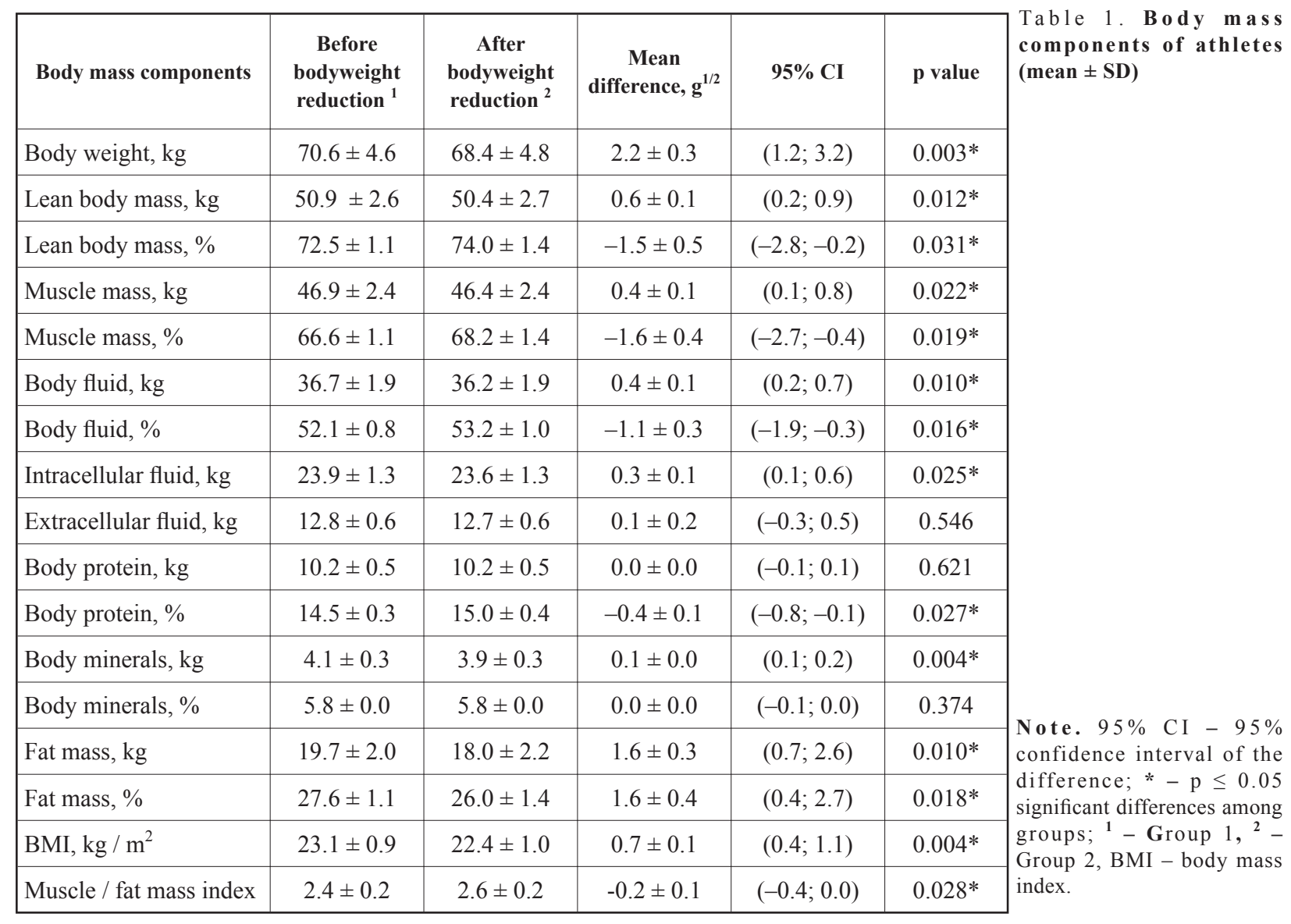


Table 2. Amino acids in athletes' food rations (mean $\pm \mathrm{SD})$

Note. $95 \%$ CI $95 \%$ confidence interval of the difference; * $\mathrm{p} \leq 0.05$ significant differences among groups , ${ }^{1}$ - Group $1,{ }^{2}-$ Group 2.

\begin{tabular}{|c|c|c|c|c|c|c|}
\hline $\begin{array}{c}\text { Amino acids, } \\
\mathrm{g} \cdot \mathrm{day}^{-1}\end{array}$ & $\begin{array}{c}\text { Before } \\
\text { bodyweight } \\
\text { reduction }^{1}\end{array}$ & $\begin{array}{c}\text { During } \\
\text { bodyweight } \\
\text { reduction }^{2}\end{array}$ & $\begin{array}{c}\text { Mean } \\
\text { difference } \\
(\mathrm{g})^{1 / 2}\end{array}$ & $95 \% \mathrm{CI}$ & p value & Recommendation \\
\hline Essential & $38.5 \pm 3.1$ & $22.7 \pm 1.1$ & $15.8 \pm 3.7$ & $(5.4 ; 26.2)$ & $0.013 *$ & - \\
\hline Valine & $5.8 \pm 0.5$ & $3.4 \pm 0.2$ & $2.5 \pm 0.6$ & $(0.7 ; 4.2)$ & $0.016^{*}$ & $3-4$ \\
\hline Izoleucine & $4.7 \pm 0.4$ & $2.9 \pm 0.1$ & $1.8 \pm 0.4$ & $(0.6 ; 3.0)$ & $0.014^{*}$ & $3-4$ \\
\hline Leucine & $8.3 \pm 0.7$ & $5.0 \pm 0.2$ & $3.3 \pm 0.8$ & $(1.0 ; 5.6)$ & $0.016^{*}$ & $4-6$ \\
\hline Lysine & $7.0 \pm 0.6$ & $4.1 \pm 0.2$ & $3.0 \pm 0.7$ & $(0.1 ; 4.9)$ & $0.014^{*}$ & $3-5$ \\
\hline Methionine & $2.3 \pm 0.2$ & $1.4 \pm 0.1$ & $0.9 \pm 0.2$ & $(0.3 ; 1.6)$ & $0.017^{*}$ & $2-4$ \\
\hline Treonine & $4.0 \pm 0.3$ & $2.3 \pm 0.1$ & $1.7 \pm 0.3$ & $(0.7 ; 2.6)$ & $0.009 *$ & $2-3$ \\
\hline Tryptophan & $1.5 \pm 0.1$ & $0.7 \pm 0.0$ & $0.7 \pm 0.1$ & $(0.3 ; 1.1)$ & $0.008 *$ & 1 \\
\hline Phenylalanine & $4.8 \pm 0.4$ & $2.9 \pm 0.1$ & $1.9 \pm 0.4$ & $(0.7 ; 3.2)$ & $0.013 *$ & $2-4$ \\
\hline Non-essential, g & $65.8 \pm 4.9$ & $42.5 \pm 1.7$ & $23.3 \pm 5.8$ & $(7.1 ; 39.5)$ & $0.016^{*}$ & - \\
\hline Arginine & $5.0 \pm 0.3$ & $3.1 \pm 0.2$ & $1.9 \pm 0.4$ & $(0.7 ; 3.1)$ & $0.012 *$ & $5-6$ \\
\hline Histidine & $3.3 \pm 0.3$ & $1.6 \pm 0.1$ & $1.7 \pm 0.4$ & $(0.6 ; 2.7)$ & $0.01 *$ & $1,5-2$ \\
\hline Tyrosine & $4.0 \pm 0.3$ & $2.3 \pm 0.1$ & $1.7 \pm 0.4$ & $(0.6 ; 2.9)$ & $0.013 *$ & $3-4$ \\
\hline
\end{tabular}

Table 3. Energy and macronutrients intake of athletes' $($ mean \pm SD)

Note: $95 \% \mathrm{CI}-$ 95\% confidence interval of the difference; *$\mathrm{p} \leq 0.05$ significant differences among groups; ${ }^{1}$ - Group $1,{ }^{2}-$ Group 2.

\begin{tabular}{|c|c|c|c|c|c|}
\hline Energy value and macronutrients & $\begin{array}{c}\text { Before } \\
\text { bodyweight } \\
\text { reduction }{ }^{1}\end{array}$ & $\begin{array}{c}\text { During } \\
\text { bodyweight } \\
\text { reduction }^{2}\end{array}$ & $\begin{array}{c}\text { Mean } \\
\text { difference } \\
(\mathrm{g})^{1 / 2}\end{array}$ & $95 \% \mathrm{CI}$ & p value \\
\hline Protein, $\mathrm{g} \cdot \mathrm{kg}^{-1} \cdot$ day $^{-1}$ & $1.5 \pm 0.2$ & $1.0 \pm 0.0$ & $0.5 \pm 0.2$ & $(0.1 ; 1.0)$ & $0.024 *$ \\
\hline Fat, $\mathrm{g} \cdot \mathrm{kg}^{-1} \cdot$ day $^{-1}$ & $1.6 \pm 0.2$ & $0.6 \pm 0.0$ & $0.9 \pm 0.2$ & $(0.4 ; 1.4)$ & $0.008 *$ \\
\hline Cholesterol, $\mathrm{mg} \cdot$ day $^{-1}$ & $0.9 \pm 0.2$ & $0.1 \pm 0.1$ & $0.8 \pm 0.2$ & $(0.3 ; 1.4)$ & $0.015^{*}$ \\
\hline Saturated fatty acids, $g \cdot$ day $^{-1}$ & $45.5 \pm 4.8$ & $16.4 \pm 1.3$ & $29.1 \pm 5.0$ & $(15.3 ; 43)$ & $0.004^{*}$ \\
\hline Polisaturated fatty acids, $\mathrm{g} \cdot$ day $^{-1}$ & $17.2 \pm 1.5$ & $7.1 \pm 0.8$ & $10.1 \pm 2.1$ & $(4.2 ; 16)$ & $0.009^{*}$ \\
\hline Linolic acid, $g \cdot$ day $^{-1}$ & $15.4 \pm 1.4$ & $6.2 \pm 0.8$ & $9.2 \pm 2.0$ & $(3.6 ; 14.9)$ & $0.010^{*}$ \\
\hline Linoleic acid, $g \cdot$ day $^{-1}$ & $1.3 \pm 0.2$ & $0.1 \pm 0.1$ & $1.2 \pm 0.2$ & $(0.5 ; 1.8)$ & $0.007 *$ \\
\hline Carbohydrate, $\mathrm{g} \cdot \mathrm{kg}^{-1} \cdot$ day $^{-1}$ & $5.0 \pm 0.4$ & $4.4 \pm 0.2$ & $0.6 \pm 0.4$ & $(-0.4 ; 1.6)$ & 0.190 \\
\hline Dietary fiber, $g \bullet$ day $^{-1}$ & $31.8 \pm 3.0$ & $25.9 \pm 1.4$ & $5.9 \pm 3.6$ & $(-4.2 ; 16)$ & 0.180 \\
\hline Energy intake, ccal $\cdot$ day $^{-1}$ & $2781 \pm 210$ & $1845 \pm 76$ & $936 \pm 226$ & $(307 ; 1564)$ & $0.014 *$ \\
\hline Energy intake, $\mathrm{g} \cdot \mathrm{kg}^{-1} \cdot$ day $^{-1}$ & $40.0 \pm 3.8$ & $27.2 \pm 0.9$ & $12.8 \pm 3.4$ & $(3.3 ; 22.3)$ & $0.020^{*}$ \\
\hline \multicolumn{6}{|c|}{ Providing percentage (\%) of total energy intake from: } \\
\hline Carbohydrate, $\%$ & $50.3 \pm 1.9$ & $64.8 \pm 1.1$ & $-14.6 \pm 1.9$ & $(-19.9 ;-9.2)$ & $0.002 *$ \\
\hline Protein, $\%$ & $15.0 \pm 0.5$ & $14.0 \pm 0.0$ & $1.0 \pm 0.5$ & $(-0.5 ; 2.5)$ & 0.13 \\
\hline Fat, \% & $34.7 \pm 1.5$ & $20.8 \pm 1.1$ & $13.9 \pm 1.4$ & $(10 ; 17.9)$ & $0.001 *$ \\
\hline
\end{tabular}

Athletes' diets lacked vitamins D, PP, $\mathrm{B}_{1}$, and folic acid. The amount of vitamin $D$ was $3.5 \pm 0.7 \mu \mathrm{g}$ (and the recommended norm is $5 \mu \mathrm{g}$ ); $\mathrm{B}_{1}-1.4 \pm 0.1 \mathrm{mg}$ (the recommended norm is $2 \mathrm{mg}$ ); PP- $21.3 \pm 0.9 \mathrm{mg}$ (the recommended norm is $22 \mathrm{mg}$ ); folic acid $-247.5 \pm 16.3 \mu \mathrm{g}$ (the recommended norm is $300 \mu \mathrm{g}$ ). The amounts of minerals in athletes' nutrition are close to the recommended norms (Figures 2 and 3).
Having evaluated some indices of female basketball players' physical state in the laboratory tests (Table 2) we established that their muscle mass, which was $66.7 \pm 1.1 \%$ of the whole body mass on average, fit into the recommended limits: form 64 to $80 \%$, and the muscle mass of both arms and legs did not differ. Athletes' BMI was $23.1 \pm 0.9 \mathrm{~kg} / \mathrm{m}^{2}$, and it is evaluated as adequate (from $19 \mathrm{~kg} / \mathrm{m}^{2}$ to $24 \mathrm{~kg} / \mathrm{m}^{2}$ ), their MFMI - as 

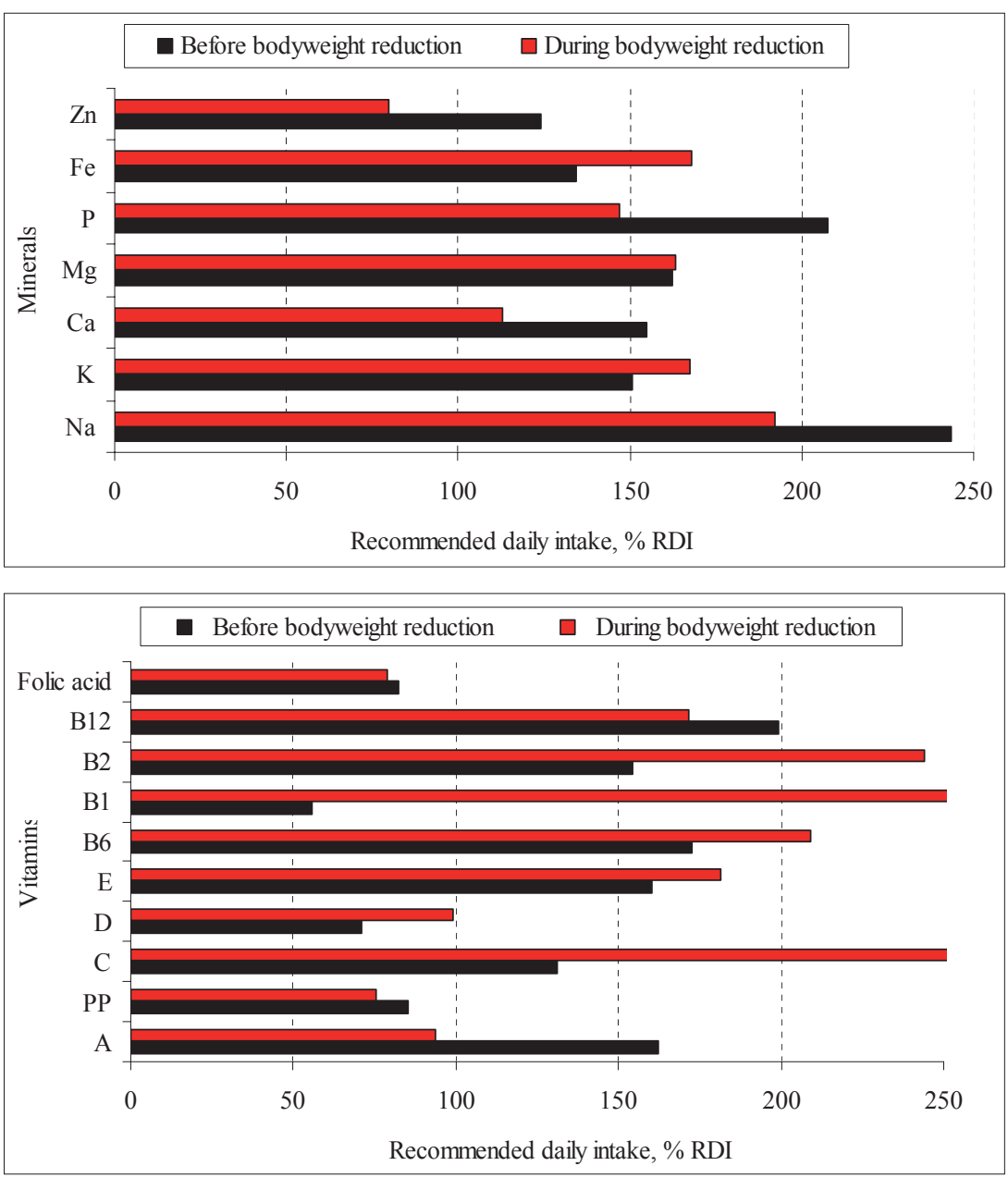

Figure 2. Mineral intake of athletes

Figure 3. Vitamin intake of athletes too low $2.4 \pm 0.2$ (from 1.9 to 2.8 ) because their fat body mass, which was $27.6 \pm 1.1 \%$ of the whole body mass on average, is slightly too high, but it is evaluated as acceptable (from 25 to $29 \%$ ). Thus, aiming at achieving better technical and tactical fitness, and consequently better results, Lithuanian Olympic Sport Centre female basketball players reduced their body fat and increased their MFMI. For this purpose they received individual food rations with reduced energy values (Table 2). As the food rations before the moderate body mass reduction program lacked vitamins $\mathrm{B}_{1}, \mathrm{D}, \mathrm{PP}$ and folic acid, their food rations were supplemented by "Vitamax" food supplement capsules, and the amounts of vitamins and minerals during the body mass reduction program were close to the recommended norms (Figures 2 and 3 ).

During the moderate body mass reduction period, female athletes' overall body mass decreased statistically significantly $-2.2 \pm 0.3 \mathrm{~kg}$ $(\mathrm{p}=0.003)$, their lean body mass $-0.6 \pm 0.1 \mathrm{~kg}$ $(\mathrm{p}=0.012)$, muscle mass $-0.4 \pm 0.1 \mathrm{~kg}(\mathrm{p}=0.022)$, general body fluids $-0.4 \pm 0.1 \mathrm{~kg}(\mathrm{p}=0.01)$, intracellular fluids $-0.3 \pm 0.1 \mathrm{~kg}(\mathrm{p}=0.025)$, amount of minerals $-0.1 \pm 0.01 \mathrm{~g}(\mathrm{p}=0.004)$, however, the amount of proteins remained unaltered $(\mathrm{p}=0.621)$ (Table 1). MFMI increased from $2.4 \pm 0.2$ to $2.6 \pm 0.2(\mathrm{p}=0.028)$, thus we suggest that when the lean body mass decreases at the expense of fluids, the loss of body fat mass $1.6 \pm 0.3 \mathrm{~kg}(\mathrm{p}=0.010)-$ was useful to basketball players aiming at increasing the ratio between muscle mass and fat mass.

After evaluating the influence of reduced energy value nutrition on the changes in athletes' body fat mass, we established that the reduction of body fat mass was mostly linked to the reduced energy value of athletes' food rations and the lower amount of fats $(\mathrm{r}=0.8$ and $\mathrm{r}=0.7)$, as well as lower amount of carbohydrates $(r=0.6)$.

The indices of fat metabolism in athletes' blood (Ch, MTL Ch, DTL Ch, TG) did not differ statistically significantly before and after the reduced energy value nutrition of moderate duration. Ch concentration before and after the reduced energy value nutrition was between $3.7 \pm 0.6 \mathrm{mmol} / 1$ and $3.5 \pm 0.4 \mathrm{mmol} / 1(\mathrm{p}=0.19)$, MTL Ch - from $1.9 \pm 0.5 \mathrm{mmol} / 1$ and $1.8 \pm 0.3$ $\mathrm{mmol} / 1(\mathrm{p}=0.4)$, DTL Ch $-1.2 \pm 0.3 \mathrm{mmol} / 1$ and $1.1 \pm 0.1 \mathrm{mmol} / 1(\mathrm{p}=0.62), \mathrm{TG}-1.2 \pm 0.3$ 
$\mathrm{mmol} / 1$ and $1.1 \pm 0.3 \mathrm{mmol} / 1(\mathrm{p}=0.68)$. However, there was statistically significant reduction in Glu concentration in blood (from $5.04 \pm 0.18 \mathrm{mmol} / 1$ to $4.6 \pm 0.16 \mathrm{mmol} / 1(\mathrm{p}=0.02))$. Reduced Glu concentration was linked to lower energy value in food $(r=0.9)$ and lower amount of carbohydrates $(\mathrm{r}=0.9)$.

After evaluating the difference in $\mathrm{PWC}_{170}$ indices before and after the moderate body mass reduction, we established that $\mathrm{PWC}_{170}$ indices before and after the moderate body mass reduction statistically significantly decreased from $1245 \pm 150 \mathrm{kgm} / \min (18 \pm 1.3 \mathrm{kgm} / \mathrm{min} / \mathrm{kg})$ to $1035 \pm 205 \mathrm{kgm} / \min (15 \pm 0.6 \mathrm{kgm} / \mathrm{min} / \mathrm{kg})$ $(\mathrm{p}=0.01)$. We established statistically significant relationship between reduced Glu concentration in blood and reduced $\mathrm{PWC}_{170}\left(\mathrm{R}^{2=} 0.49\right)$.

\section{DISCUSSION}

In the last decade athletes' nutrition has not changed: elite athletes' diets lack carbohydrates, the amount of fat is too high, and the amount of proteins is efficient (Baranauskas et al., 2007, 2009; Pečiukonienè et al., 2007, 2009; Stukas et al., 2009). Lithuanian Olympic Sport Centre female basketball players are no exception. Their food rations have too much saturated fat acids, linoleic cat acids, but they lack carbohydrates, indispensable amino acid methionine and linolenic fat acid, and the amount of proteins is sufficient. Besides, our research participants' nutrition lacked vitamins $\mathrm{D}, \mathrm{B}_{1}$ and folic acid, but the indices of minerals compared to the nutrition of elite athletes were closer to the recommended norms.

Our research results proved that during the moderate body mass reduction diets rich in carbohydrates, lacking fats and cholesterol and having low energy values were efficient in reducing athletes' fat body mass, and they did not affect the indices of fat metabolism in female basketball players' blood. Our findings confirmed the findings of other researchers (Hortobagyi et al., 2004; Kersick, 2009; Stukas et al., 2009) who found that peculiarities of athletes' nutrition did not significantly affect fat metabolism in blood, and those changes were due to physical activities and genetic factors, but not the amount of cholesterol in food (Bui et al., 2010).

Reduction of body fat mass of female basketball players more depended on the energy values of their food rations that on the balance of the main nutrients in their food. Lower amount of carbohydrates than recommended $(4.4 \pm 0.2 \mathrm{~g} / \mathrm{k}$ of body mass) negatively influenced concentration of glucoses in blood and aerobic working capacity, but it was sufficient for the maintenance of normal concentration of glucoses and hormone insulin in blood. This amount was enough for the supplies of glycogen to remain only partly reduced. Consequently, the amount of proteins in food rations of basketball female players, which was $1.0 \pm 0.0 \mathrm{~g} / \mathrm{kg}$ of body mass on average, was able to meet their needs. This was confirmed by statistically significant difference found in the amount of proteins in athletes' organisms before and after body mass reduction. On the other hand, athletes' body mass was reduced at the expense of fluids, and the losses were $0.4 \pm 0.1 \mathrm{~kg}$ : with the reduced amounts of glycogen athletes lose water as well.

So, the 12-day period of female basketball players' body mass reduction is not optimal when the energy value of food is reduced by $936 \pm 226 \mathrm{kcal}$ on average compared to the usual values because it can negatively impact aerobic working capacity, only if 4 days before the competitions, aiming at increasing the amount of endogenous glycogen in muscles and improving the indices of aerobic working capacity the athletes increased the energy value of their food by $30 \%$ and the amount of carbohydrates - to $8 \mathrm{~g} / \mathrm{kg}$ of body mass a day (Tarnopolsky et al., 2001) because otherwise, under the conditions of longer and more intensive training, their supplies of carbohydrates would run out more, and if they were not regained with food, their bodies could suffer form the increased amount of hormone cortisol and reduced concentration of testosterone (Vaszquez, Adibi, 1992; Remer, 2001), metabolic acidosis and reduced lean body mass (GougeonReyburn et al., 1991; Layman et al., 2005; Mero et al., 2010) could be observed as well as indices of aerobic and anaerobic working capacity.

\section{CONCLUSIONS AND PERSPECTIVES}

The main nutrients of food rations of Lithuanian Olympic Sport Centre female basketball players are not balanced. The misbalance is mainly conditioned by the reduced amount of carbohydrates and too much fat in athletes' food. Vitamins D, PP, $B_{1}$ and folic acid in food do not reach the recommended norms for the day, though the amounts of minerals are close to the recommended norms. 
Low energy value nutrition of moderate duration, when the energy value of food is lower by $1000 \mathrm{kcal}$ than the regular one, and the percentages of energy values from carbohydrates, proteins and fats are respectively 65,14 and $21 \%$, is efficient in increasing the ratio of athletes' muscle mass and fat mass $(\mathrm{p}<0.05)$, but it negatively affects glucose concentration in blood as well as aerobic capacity $(\mathrm{p}<0.05)$.
Basketball players' nutrition with little fat and low in energy value for a very short time affects fat metabolism in athletes' organisms: the fat body mass reduces $(\mathrm{p}<0.05)$, but it does not affect the concentration of general cholesterol $(p>0.05)$, low density lipoprotein cholesterol $(\mathrm{p}>0.05)$, high density lipoprotein cholesterol $(\mathrm{p}>0.05)$ and triacylglycerol $(\mathrm{p}>0.05)$ in blood plasma.

\section{REFERENCES}

Balčiūnas, M., Matulaitis, K., Stonkus, S. (2009). Ivairaus amžiaus krepšininku pagrindiniai fizinio ir techninio parengtumo rodikliai ir jų kaita. Sporto mokslas, 2 (56), $58-64$.

Baranauskas, M., Tubelis, L., Pečiukonienė, M., Stukas R., Švedas, E. (2007 a). Jaunuju sportininkų mitybos organizavimo ivertinimas. Sporto mokslas, 2 (48), 7177.

Baranauskas, M., Tubelis, L., Stukas, R., Švedas, E. (2009 a). Lietuvos olimpinès rinktinès ištvermès sporto šakas kultivuojančiu sportininku faktinès mitybos itaka energijos eikvojimui fizinio krūvio metu. Sporto mokslas, 4 (58), 26-33

Baranauskas, M., Tubelis, L., Stukas, R., Švedas, E. (2009 b). Lietuvos olimpinio sporto centro sportininku mitybos tyrimas. Sporto mokslas, 3 (57), 40-48.

Baranauskas, M., Tubelis, L., Stukas, R. Švedas, E. (2007 b). Sportininku pasitenkinimo organizuotu maitinimu tyrimas. Sporto mokslas, 4 (50), 40-46.

Bui, S., Oliver, J., Mardock, M., Beihl, A., Riechman, S. E. (2010). High egg cholesterol consumption may not affect blood serum cholesterol levels in elite athletes in training. The Journal of the Federation of American Societies for Experimental Biology, 24, 628.

Gougeon-Reyburn, R., Lariviere, F., Marliss, E. B. (1991). Effects of bicarbonate supplementation on urinary mineral excretion during very low energy diets. The American Journal of the Medical Sciences, 302, 67-74.

Hortobágyi, T., Houmard, J. A., Israel, I., Barahat, H. A. (2004). Effects of exercise cessation on lipids and lipoproteins in distance runners and power athletes. European Journal of Applied Physiology and Occupational Physiology, 67 (3), 226-230.

Kersick, C., Tucker, P., Roberts, M. et al. (2009). The combined effects of exercise training and ingestion of weight loss supplement on body composition and fitness parameters in college-aged males and females. Journal of the International Society of Sports Nutrition, 6, 19.

Layman, D. K., Evans, E., Baum, J. I. et al. (2005). Dietary protein and exercise have additive effects on body composition during weight loss in adult women. Journal of Nutrition, 135, 1903-1910.

Mero, A. A., Huovinen, H., Matintupa, O. et al. (2010). Moderate energy restriction with high protein diet results in healther outcome in women. Journal of the International Society of Sports Nutrition, 7, 4.

Pečiukonienè, M., Stukas, R., Kemerytè-Riaubienè, E., Dadeliené, R. (2007). Kai kurių Lietuvos didžiausio meistriškumo sportininkų maisto racionu charakteristika. Sporto mokslas, 4 (50), 28-33.

Pečiukonienè, M., Stukas, R., Kemerytė-Riaubienė, E. (2009). Sportininkų mitybos, fizinio išsivystymo ir imičio būklès tyrimas bei jų tarpusavio sąsajų vertinimas. Sporto mokslas, 1 (55), 42-49.

Remer, T. (2001). Influence of nutrition on acid-base balance-metabolic aspects. European Journal of Nutrition, 40, 214-220.

Skernevičius, J, Raslanas, A., Dadelienè, R. (2004). Fizinio darbingumo ir kraujotakos sistemos funkcinio pajègumo nustatymas $\mathrm{PWC}_{170}$ testu. Sporto mokslo tyrimu metodologija, 149-153.

Stukas, R., Pečiukonienė, M., Kemerytė-Riaubienè, E., Baškienė, V. (2009). Kai kurie riebalu apykaitos sportininku organizme ypatumai. Sporto mokslas, 2 (56), 44-49.

Sučilienè, S., Abaravičius, A. (2002). Maisto produktu sudetis. Vilnius.

Tarnopolsky, M. A, Zawada, C., Richmond, L. B., Carter, S. (2001) Gender differences in carbohydrate loading are related to energy intake. Journal of Applied Physiology, 91, 225-230.

Vaszquez, J. A., Adibi, S. A. (1992). Protein sparing during treatment of obesity: Ketogenic versus nonketogenic very low caloric diet. Metabolism, 41, 406-414.

Wilmore, J. H. (2000). Weight category sports. In R. J. Maughan (Ed.), Nutrition in Sport. Oxford, UK: Blackwell Science Ltd. P. 637-645. 


\title{
KAI KURIE LIETUVOS OLIMPINIO SPORTO CENTRO KREPŠININKIŲ MITYBOS IR KŪNO MASĖS MAŽINIMO YPATUMAI
}

\author{
Marius Baranauskas ${ }^{1,3}$, Linas Tubelis ${ }^{2,3}$, Rimantas Stukas ${ }^{1}$, Edmundas Švedas $^{4}$, \\ Laimutė Samsoniené ${ }^{5}$, Diana Karanauskien $\dot{e}^{6}$ \\ Vilniaus universiteto Visuomenés sveikatos institutas, Vilnius, Lietuval \\ Vilniaus pedagoginis universitetas, Vilnius, Lietuva ${ }^{2}$ \\ Lietuvos olimpinis sporto centras, Vilnius, Lietuva ${ }^{3}$ \\ Vilniaus sporto medicinos centras, Vilnius, Lietuva ${ }^{4}$ \\ Vilniaus universiteto sporto ir sveikatos centras, Vilnius, Lietuva ${ }^{5}$ \\ Lietuvos kūno kultūros akademija, Kaunas, Lietuva ${ }^{6}$
}

\section{SANTRAUKA}

Tyrimo pagrindimas ir hipotezė. Didelio meistriškumo sportininkai, norèdami sumažinti kūno masę, dažnai praktikuoja sumažintos energinès vertès labai nedaug angliavandenių turinčią mitybą. Visgi specialistai pastebi, kad itin svarbu nustatyti, kokią itaką daro saugesnè vidutinès trukmès daug angliavandenių turinti sumažintos energinès vertès mityba sportininkų kūno masei ir fiziniam darbingumui.

Tikslas: ištirti ir įvertinti Lietuvos olimpinio sporto centro krepšininkių $(n=10)$ faktinę mitybą ir vidutinès trukmès sumažintos energinès vertès mitybos daromą įtaką kūno masei ir jos komponentams, aerobiniam darbingumui bei kai kuriems kraujo biocheminiams rodikliams.

Metodai. Tikslui pasiekti prieš sumažintos energinès vertès mitybą ir jos metu ištirta sportininkių faktinè mityba. Prieš mažinant kūno masę ir po to įvertinti kai kurie fizinio išsivystymo rodikliai, kraujo riebalų apykaitos rodiklių (bendrojo cholesterolio, mažo ir didelio tankio lipoproteinų cholesterolio, triacilglicerolių) bei gliukozės koncentracija. Aerobinis darbingumas nustatytas atlikus $\mathrm{PWC}_{170}$ testą.

Rezultatai. Krepšininkių maisto racionuose pagrindinès maistinès medžiagos nesubalansuotos, nes angliavandenių, linoleno riebalų rūgšties, nepakeičiamos aminorūgšties metionino, vitaminų $\mathrm{D}, \mathrm{PP}, \mathrm{B}_{1}$, folio rūgšties kiekiai nesiekia rekomenduojamų, o riebalų kiekis, priešingai, - rekomenduojamą viršija. Kūno masės mažinimo metu krepšininkių kūno masé, riebalų masė, organizmo mineralinių medžiagų kiekiai sumažejo atitinkamai 2,2 $\pm 0,3 \mathrm{~kg}(\mathrm{p}<0,05), 1,6 \pm 0,3 \mathrm{~kg}(\mathrm{p}<0,05), 0,1 \pm 0,4 \mathrm{~kg}(\mathrm{p}<0,05)$, tačiau nekito jų organizmo baltymu kiekis $(\mathrm{p}>0.05)$.

Aptarimas ir išvados. Norint nepabloginti fizinio darbingumo rodiklių, vidutinès trukmès sumažintos energinès vertès mityba, kurios energinè vertè sudaro mažiau kaip $30 \mathrm{kcal} / \mathrm{kg}$ kūno masès, o angliavandenių kiekis joje mažiau kaip $<5 \mathrm{~g} / \mathrm{kg}$ kūno masės per dieną, sportininkams yra nerekomenduojama.

Raktažodžiai: mityba, moterų krepšinis, kūno masės mažinimas.

Gauta 2011 m. kovo 17 d.

Received on March 17, 2011

Priimta 2011 m. birželio 16 d.

Accepted on June 16, 2011

Corresponding author Marius Baranauskas

Lithuanian Olympic Sport Center

Ozo str. 39, Vilnius LT-07171

Lithuania

Tel 868384462

E-mail marius.baranauskas9@gmail.com 